\title{
Above Ground Biomass Assessment from Combined Optical and SAR Remote Sensing Data in Surat Thani Province, Thailand
}

\author{
Kilaparthi Kiran Kumar, Masahiko Nagai, Apichon Witayangkurn, \\ Kunnaree Kritiyutanant, Shinichi Nakamura \\ School of Engineering and Technology, Asian Institute of Technology, Bangkok, Thailand \\ Email: kilaparthi.kiran@gmail.com,nagaim@ait.asia, apichon@ait.asia, \\ Kunnaree.kr@gmail.com,nakamura@ait.asia
}

Received 18 July 2016; accepted 21 August 2016; published 24 August 2016

Copyright (C) 2016 by authors and Scientific Research Publishing Inc.

This work is licensed under the Creative Commons Attribution International License (CC BY). http://creativecommons.org/licenses/by/4.0/

\section{Open Access}

\begin{abstract}
Today the carbon content in the atmosphere is predominantly increasing due to greenhouse gas emission and deforestation. Forest plays a key role in absorbing carbon dioxide from atmosphere by process of sequestration through photosynthesis and stores in form of wood biomass which contains nearly $70 \%-80 \%$ of global carbon. Different forms of biomass in the environment include agricultural products, wood, renewable energy and solid waste. Therefore, it is essential to estimate the biomass content in the environment. In olden days, biomass is estimated by forest inventory techniques which consume lot of time and cost. The spatial distribution of biomass cannot be obtained by traditional inventory forest techniques so the application of remote sensing in biomass assessment is introduced to solve the problem. Overall accuracy of classified map indicates that land features of Surat Thani on map show an accuracy of $91.13 \%$ with different land features on ground. Both optical (LANDSAT-8) and synthetic aperture radar (ALOS-2) remote sensing data are used for above ground biomass (AGB) assessment. Biomass that stores in branch and stem of tree is called as above ground biomass. Twenty ground sample plots of $30 \mathbf{m} \times \mathbf{3 0} \mathbf{m}$ utilized for biomass calculation from allometric equations. Optical remote sensing calculates the biomass based on the spectral indices of Soil Adjusted Vegetation Index (SAVI) and Ratio Vegetation Index $(\mathrm{RVI})$ by regression analysis $\left(\mathrm{R}^{2}=\mathbf{0 . 8 1 3}\right)$. Synthetic aperture radar $(\mathrm{SAR})$ is an emerging technique that uses high frequency wavelengths for biomass estimation. HV backscattering of ALOS-2 shows good relation $\left(R^{2}=0.74\right)$ with field calculated biomass compared to HH $\left(R^{2}=0.43\right)$ utilizes for biomass model generation by linear regression analysis. Combination of both optical spectral indices (SAVI, RVI) and HV (ALOS-2) SAR backscattering increases the plantation biomass accuracy to $\left(R^{2}=0.859\right)$ compared to optical $\left(R^{2}=0.788\right)$ and $\operatorname{SAR}\left(R^{2}=0.742\right)$.
\end{abstract}




\section{Keywords}

\section{Above Ground Biomass, Spectral Indices, Backscattering, LANDSAT 8, ALOS-2}

\section{Introduction}

Every year an average of 9.9 billon metric tons of carbon is releasing into atmosphere. It causes lot of threats to the global environment. The carbon emission increased due to increase usage of fossil fuels, forest deforestation etc. Forest acts as a carbon sequestration because it stores lot of carbon in the form of biomass. Due to increase in anthropogenic activities like land cover change, burning lots of fossil fuel and deforestation there is a need to produce accurate biomass for future forest ecosystem management [1]. 30\% of earth land that means 4 billion hectares is occupied by forest. For example according to Kyoto protocol [2] a forest is defined as an area of land having 0.5 - 1 hectares and crown cover greater than 10\% - 30\%. Biomass is the weight (or) mass of its living plant tissue generally expressed in metric ton. It is the organic matter present in the environment. Generally biomass can be obtained in two forms: 1) raw biomass from different sources like agricultural, forestry, agricultural crops, municipal waste and animal dropping; 2) secondary biomass obtained from primary biomass includes paper, cotton, natural rubber, card board etc. Energy released from biomass when it is burnt converted into fuels called biomass energy. Biomass provides renewable energy that improves the economy, environment and energy source. Renewable energy is eco friendly and provides less harm to the environment. Traditional inventory method is most accurate method for biomass estimation but it consumes lot of time, cost and labor. The spatial distribution of biomass in huge large cannot be calculated by inventory technique. So in order to solve this problem remote sensing techniques are utilized for biomass estimation. Due to deforestation lot of carbon content is releasing into the atmosphere and creates threads to the global environment. In general the accurate land cover change mapping is needed for finding the deforestation areas and also helps to monitor the biomass changes with time. Therefore it is important to estimate the biomass content in the environment. The application of remote sensing data becomes the primary source for biomass estimation easy and quickly for a large area. The remote sensing data consist of both optical and SAR data. Previous studies estimate the biomass by using the vegetation indices of the optical sensor data like (LANDSAT [3], SPOT [4], MODIS [5]) images. Optical remote sensing has an ability to estimate the above ground biomass because the spectral response in optical sensor data is related to the interaction between the vegetation cover and sun radiance. The biomass is estimated by determining the correlation between the spectral response and the ground data obtained from the field plots. To remove the variability caused by canopy geometry, sun view angle on biomass estimation a relationship was developed between the vegetation indices and forest biophysical parameters. It has a potential benefit in biomass estimation ranging from medium to large scales. High spatial resolution data like IKONOS [6] and WORLDVIEW-2 [7] provide the accurate biomass at local scales. For regional scales a large volume of data like LANDSAT which is medium spatial resolution data is used. At national and global scales coarse spatial resolution data like MODIS have been found useful for biomass estimation. Optical remote sensing calculates the biomass from the spectral indices. It is successful in estimating forest biomass but it is not used in the regions of cloud cover. The limitation may be overcome by the use radar data which provide additional capability of cloud free images. Different bands P, L, S, C, K, and X are used in SAR data. Out of all bands both P and L have higher wavelengths and scattered by trunks and branches of trees so they mostly used for biomass estimation. By SAR data biomass over a large area is calculated from the backscattering value. Previous studies calculate the biomass from SAR data (ALOS PALSAR-1 [8], RADARSAT [9] [10], TERRASAR-X [11], ENVISAT [12], ALOS-2 [13]). Compared to all SAR data ALOS PALSAR is the most commonly used because it has higher wavelength $\mathrm{L}$ band that penetrates more through the canopy of trees and produce high accuracy biomass. Higher wavelengths and cross polarization $(\mathrm{HV} \& \mathrm{VH})$ of SAR data show good results in biomass estimation. Application of multi frequency SAR data [14] increases the saturation effect and accuracy of biomass estimation. Dual polarization-L band (HH \& HV) is the most commonly used for tropical forest biomass estimation [15]. Different regression models are applied to generate biomass prediction model by correlating both ground data and backscatter value of SAR data. Interferometric is an emerging SAR technique and application of polarimetric [16] with interferometric increases of the biomass estimation. The combination of optical remote sensing 
with SAR data increases the accuracy level of biomass [17]. Therefore, application of different optical and SAR techniques in biomass estimation leads to understand the forest ecosystem management. The objectives of this study are: 1) land cover map of study area from landsat-8; 2) biomass model generation by regression analysis of optical spectral indices and field calculated biomass; 3) biomass map from SAR data; and 4) biomass map from combined optical and SAR remote sensing data.

\section{Study Area}

The study area is located in Mueang Surat Thani which is capital district of Surat Thani province, Thailand and geographically located on western shore of the gulf of Thailand. The geographical area of Mueang Surat Thani is $233.8 \mathrm{sq} \mathrm{km}$ and spatial co-ordinates lies between $9^{\circ} 43^{\prime} 24.08^{\prime \prime} \mathrm{N} 98^{\circ} 58^{\prime} 48.06^{\prime \prime} \mathrm{E}$ and 8 $8^{\circ} 16^{\prime} 44.65^{\prime \prime} \mathrm{N} 99^{\circ} 16^{\prime} 43.79^{\prime \prime} \mathrm{E}$. The Mueang Surat Thani flourishes with lands of fertile soil, good rainfall and balanced climatic conditions. Tapi and Phum Daung are the major rivers in this area. The Mueang Surat Thani is located at the mouth of Tapi River, which consists of eleven Tambons. The Study area is selected with 9 Tombonsof Mueang Surat Thani district because this research mainly focused on the estimation of biomass from plantations so the occurrence of plantation area in these regions is more. In this area, forest has been converted to plantations such as Oil palm, coconut and mango farms in last twenty years. Therefore it is important to estimate the spatial distribution of biomass in Surat Thani province (Figure 1).

\section{Data Collection}

\subsection{Satellite Data}

Now a day's satellite image plays a key role for solving problems because we can acquire majority of useful information from it. The accuracy of the output results mainly depends on the quality of input data utilized. In this research both optical (LANDSAT 8) and SAR (ALOS-2) data are used for biomass assessment. LANDSAT 8 optical sensor data of spatial resolution $30 \mathrm{~m}$ acquired on October 2015 is downloaded freely from USGS website. Fine beam dual polarization HH (Horizontal Horizontal) \& HV (Horizontal Vertical) of ALOS-2 acquired on October 2015 with pixel spacing of $6.25 \mathrm{~m}$ and an incident angle of $38.8^{\circ}$ is downloaded from JAXA website.

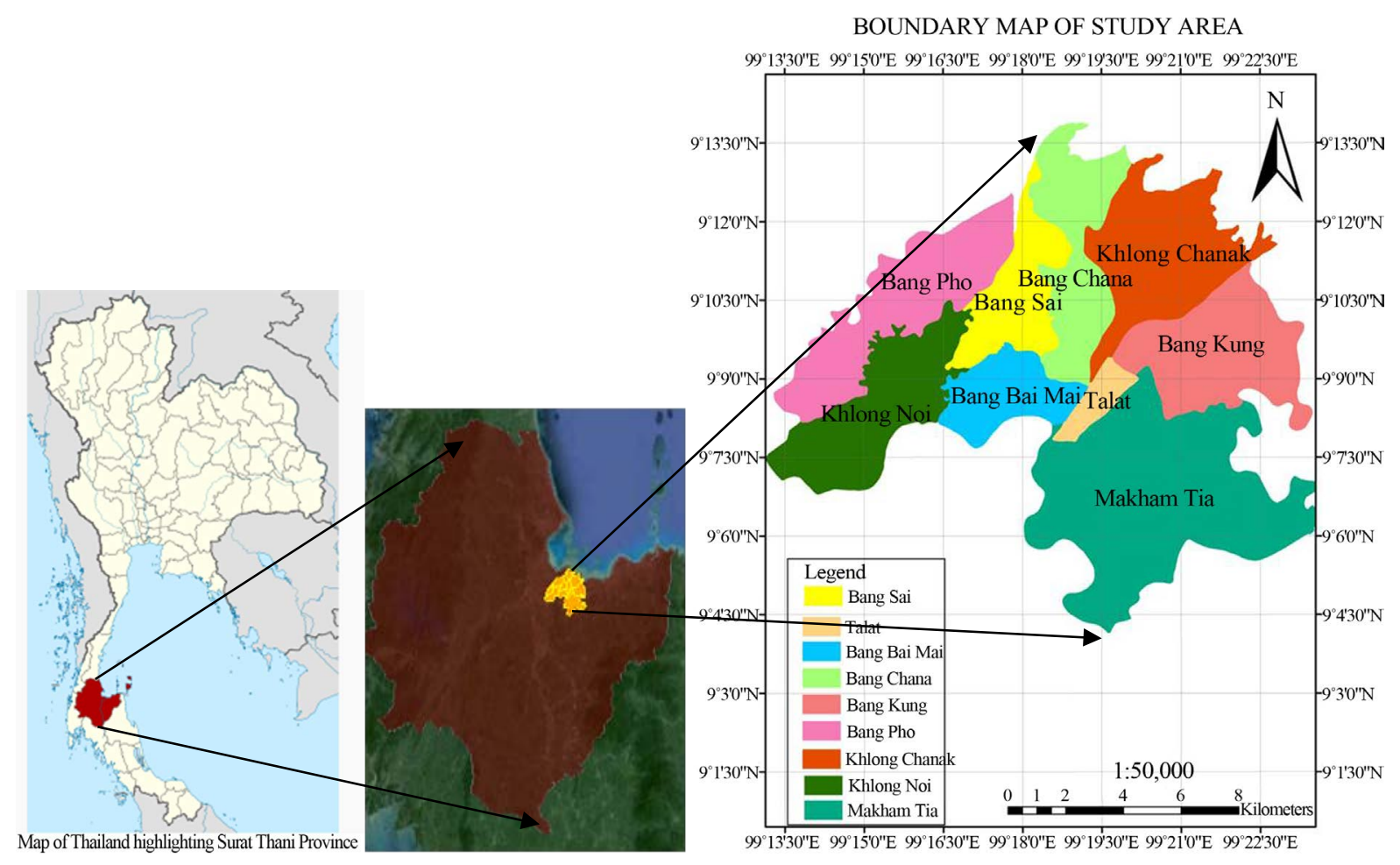

Figure 1. Location map of study area in Surat Thani province. 


\subsection{Field Data}

In this research the field data collection plays a key role in biomass estimation because the accuracy of the calculation mainly depends on the relation between satellite images and field data. The sample plots are selected in such a way it represents the whole area. The sample plot selected should be easily accessible by car or walk. In this study, random sampling method applied for selection of sample plots. For designing of sample plots the remote sensing image pixel size is considered because the biomass results are obtained from both field measurements and satellite image. From optical image (LANDSAT 8) the pixel size is $30 \mathrm{~m} \times 30 \mathrm{~m}$ so in this study, 30 $\mathrm{m} \times 30 \mathrm{~m}$ size of 20 square plots are utilized for collecting field data of both DBH (Diameter at Breast height of tree) and height of tree for each tree in square sample plot.

\section{Methodology}

\subsection{Land Cover Classification}

Raw satellite data cannot be used directly for land cover classification so initially it has to be processed by ERDAS software imagine because the satellite data collected from USGS is in different projection so it has to be transformed to WGS 84 north $47 \mathrm{~N}$ projection. In satellite data the complete information about the land surface is not stored in single band it was stored in different bands so stacking of all layers makes into a single image. Both Geometric and atmospheric corrections are applied to acquire accurate reflectance values which helps to improve the classification accuracy of image. For atmospheric correction of LANDSAT 8 image the FLAASH Atmospheric correction Model in ENVI 5.1 software is used. In this research only supervised classification is used because it extracts both quantitative and qualitative information accurately form the remote sensing image data compared to unsupervised classification. Maximum likelihood classification technique of supervised classification uses training sites which are selected for each land cover during field survey and also Google Earth as a reference to classify the satellite imagery data which produce overall classification accuracy of $91.13 \%$ and Kappa Coefficient of 0.8947. Overall accuracy of map indicates land features on map shows 91.13\% accurate with different land features on ground. From the supervised classification forest has high land coverage (83.94 sq km) fallowed by urban land (33.89 sq km), oil palm (26.92 sq km), water (13.94 sq km), coconut (6.35 sq km) and mixed plantation (5.17 sq km). Similarly mango, lemon and rose apple shows less area coverage of (0.03 0.07 sq km) (Figure 2, Figure 3).

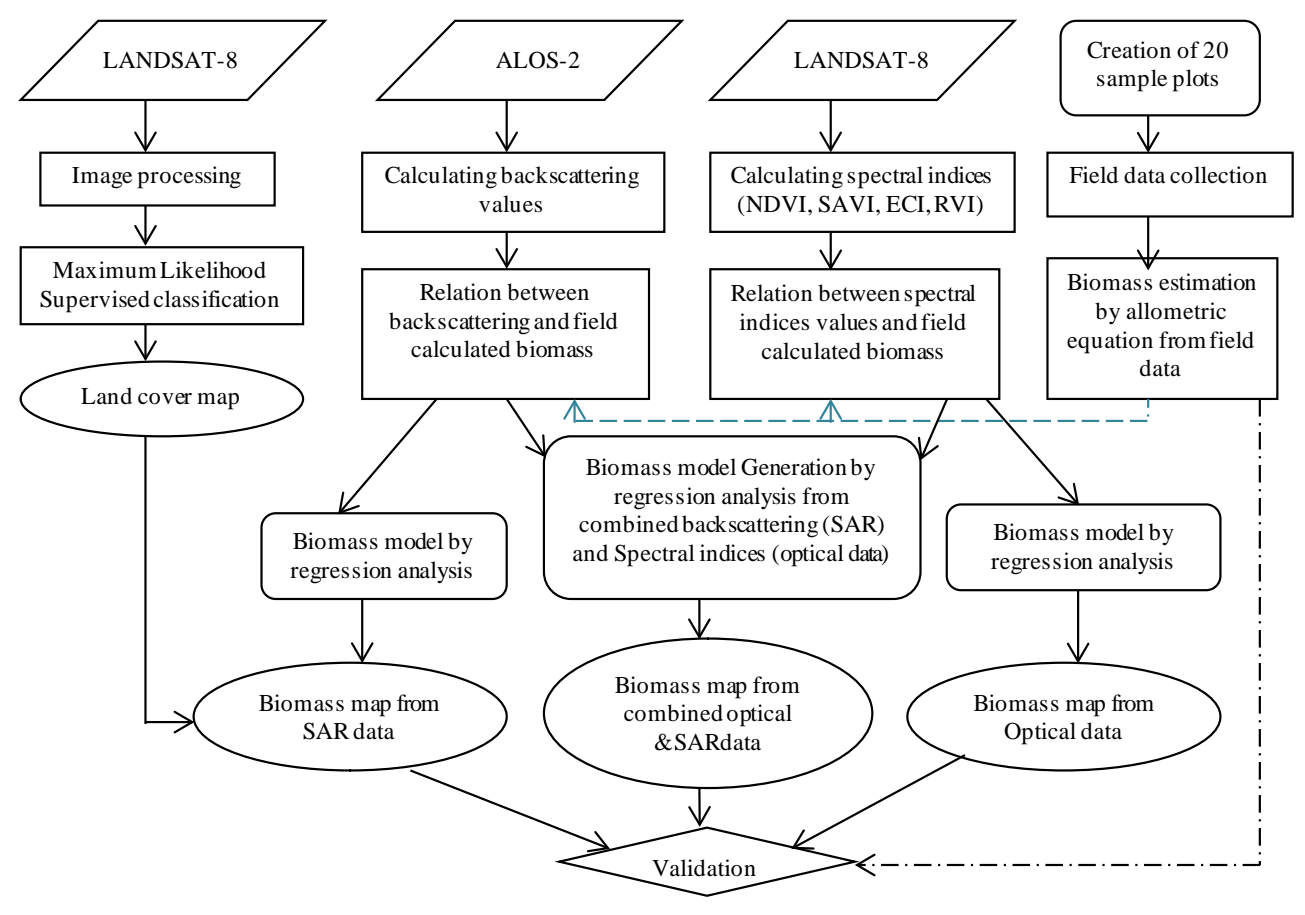

Figure 2. Overall methodology of research study. 
LAND USE LAND COVER CLASIFFICATION OF STUDY AREA

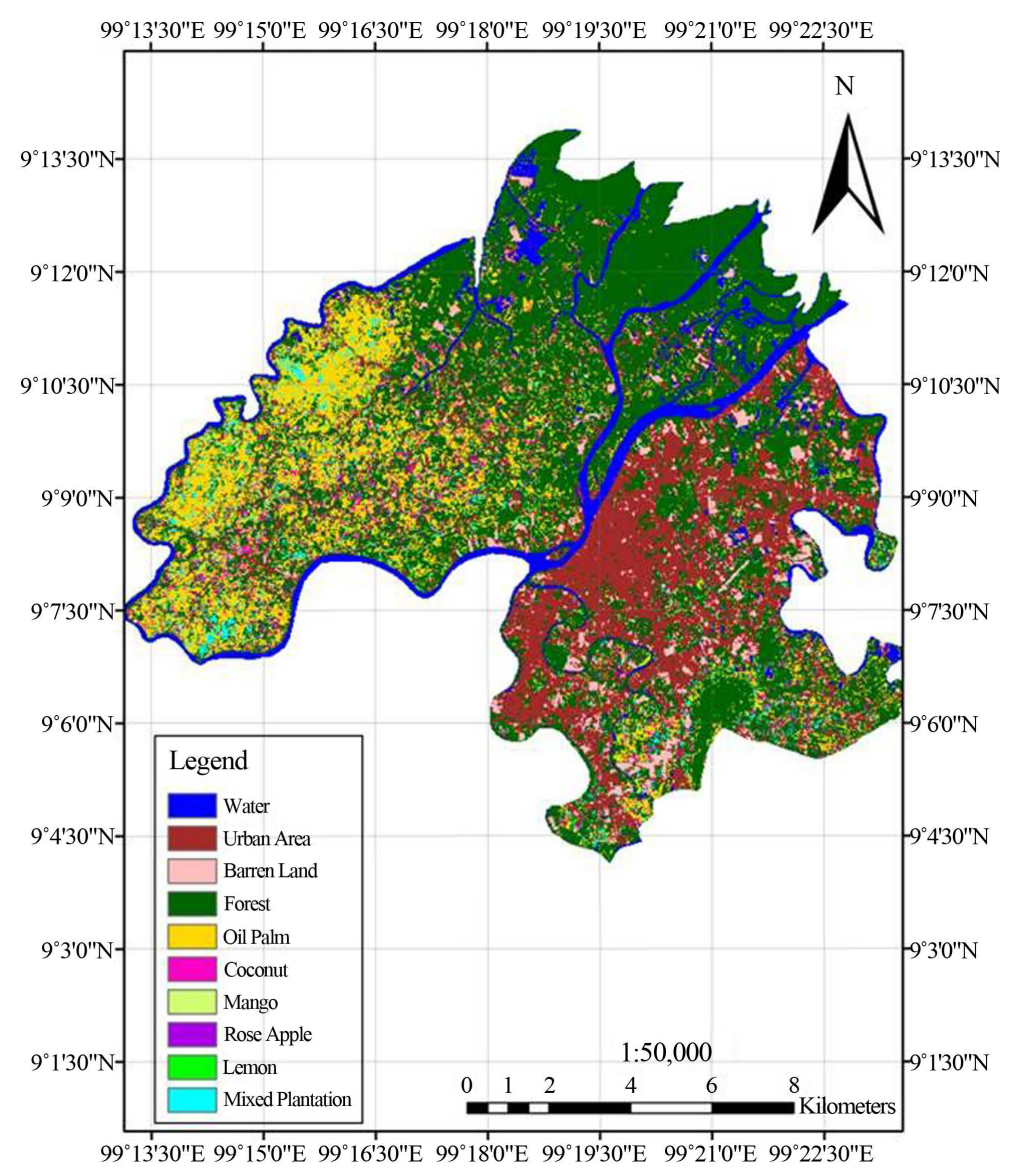

Figure 3. Land cover map of study area.

\subsection{Biomass from Optical Sensor Data}

The accuracy of estimated biomass mainly depends on the selection of appropriate allometric equations for different plantations. Allometric equations may not be same for all types of trees it changes based on 1) Species of trees and 2) selection of field data variables. In this research only two variables DBH (Diameter at breast height of tree) and tree height $(\mathrm{H})$ are utilized for calculating field biomass from allometric equations because majority allometric equations are based on these two variables. From the below Table 1 allometric equations for different plantations can be noticed.

Different allometric equations are applied for DBH and height of each tree for calculating biomass of 20 Sample plots (oil palm, mango, coconut, santol, lemon and mixed plantations). Compared to all values of field calculated biomass only oil palm plantations shows high biomass values ranging from 140 - 219 (tons/ha) (Table 2).

Spectral indices of Optical sensor data are widely used for the biomass assessment. Four different spectral indices Normalized Difference Vegetation Index (NDVI), Soil Adjusted Vegetation Index (SAVI), Ratio Vegetation Index (RVI) and Enhanced Vegetation Index (EVI) are calculated form LANDSAT-8 data and compare with the biomass calculated from field data to generate biomass model. 15 sample plots are utilized for biomass model generation by finding relation with the spectral indices of optical sensor data. Regression analysis is utilized to find new biomass model from the spectral indices of optical data which shows good relation with the field calculated biomass. SAVI $\left(\mathrm{R}^{2}=0.711\right)$, RVI $\left(\mathrm{R}^{2}=0.79\right)$ and EVI $\left(\mathrm{R}^{2}=0.74\right)$ shows good relation with field calculated biomass compared to NDVI $\left(\mathrm{R}^{2}=0.64\right)$. So NDVI is not considered in biomass model and regression analysis is applied to SAVI, RVI and EVI. Biomass model generated from combined SAVI and RVI $\left(\mathrm{R}^{2}=0.81\right)$ shows good accuracy compared to SAVI and EVI $\left(\mathrm{R}^{2}=0.75\right)$ (Figure 4). 
BIOMASS MAP OF STUDY AREA(October 2015)

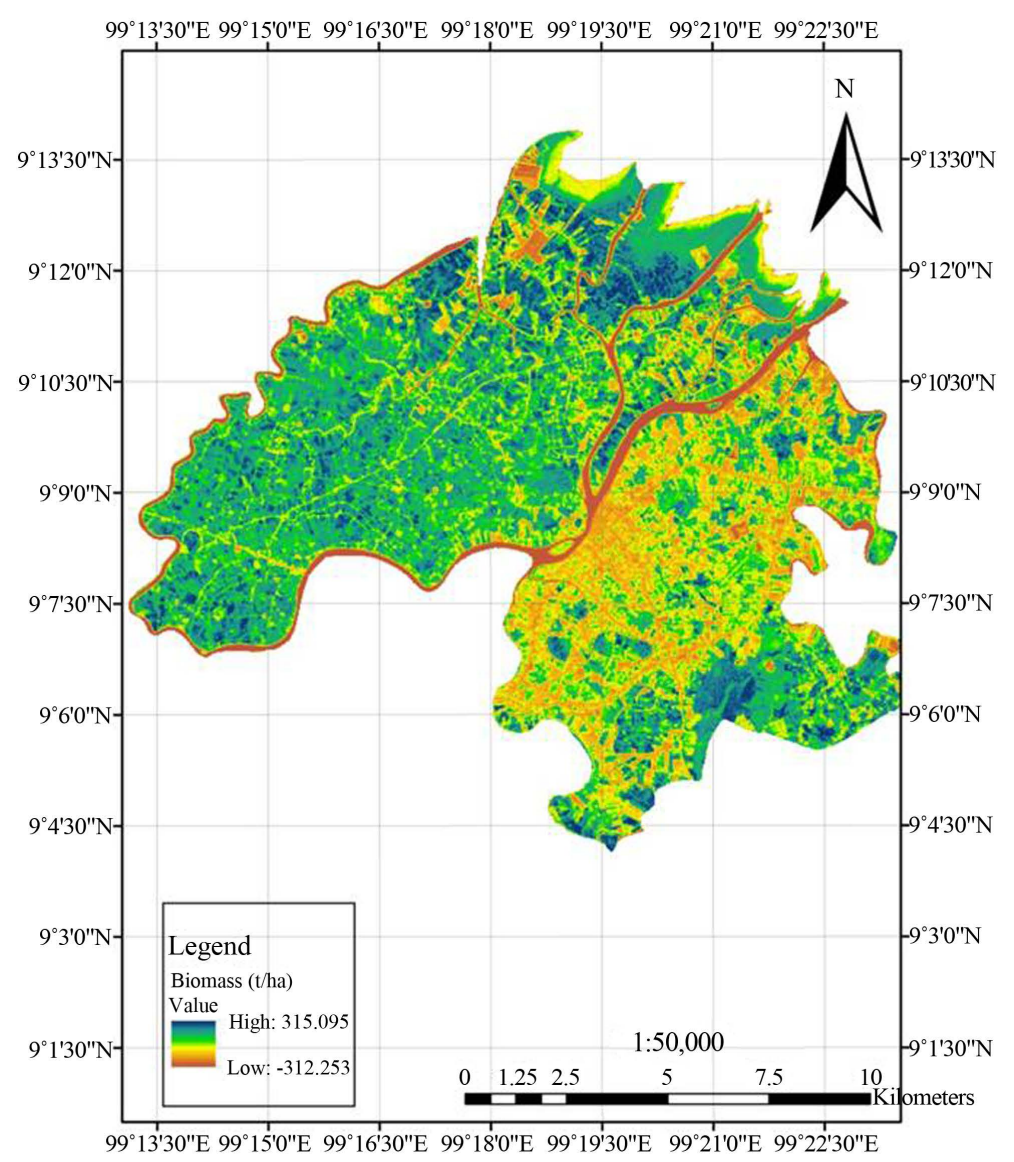

Figure 4. Biomass Map from LANDSAT-8 data.

Table 1. Allometric equations for calculation of Above ground biomass.

\begin{tabular}{|c|c|c|c|c|}
\hline S. No. & Type & Scientific name & Equation AGB & Reference \\
\hline 1 & Oil palm & Elaeis guineensis & $71.797 * \mathrm{H}-7.0872(\mathrm{~kg} /$ tree $)$ & Mazzueen Md. Khalid et al. 2013) [18] \\
\hline 2 & Banana & Musa acuminata & $0.030 \mathrm{D} 2.13(\mathrm{~kg} /$ tree $)$ & Van Noordwijik M et al. 2010) [19] \\
\hline 3 & coconut & Cocos nucifera & $4.5+7.7 * \mathrm{H}(\mathrm{kg} /$ tree $)$ & Hairiah K et al. (2010) [19] \\
\hline 4 & $\begin{array}{c}\text { Mango } \\
(\mathrm{D}<25 \mathrm{~cm})\end{array}$ & Magnifera indica & $-2.43+0.154 * \mathrm{D}+0.193 * \mathrm{H}(\mathrm{kg} /$ tree $)$ & BalbhimChavan et al. 2012) [20] \\
\hline 5 & $\begin{array}{c}\text { Mango } \\
(\mathrm{D}=25-65 \mathrm{~cm})\end{array}$ & Magnifera indica & $-26.6+0.614 * \mathrm{D}+1.39 * \mathrm{H}(\mathrm{kg} /$ tree $)$ & BalbhimChavan et al. 2012) [20] \\
\hline 6 & $\begin{array}{c}\text { Mango } \\
(\mathrm{D} \geq 65 \mathrm{~cm})\end{array}$ & Magnifera indica & $-115+1.59 * \mathrm{D}+3.38 * \mathrm{H}(\mathrm{kg} /$ tree $)$ & BalbhimChavan et al. 2012) [20] \\
\hline 7 & Lemon & Citrus & $-6.64+0.279 * \mathrm{BA}+0.000514 * \mathrm{BA}^{2}(\mathrm{~kg} /$ tree $)$ & Jackson Mwamba Bwalya 2012 [21] \\
\hline 8 & Santol & Sandoricum koetjape & $\begin{array}{l}\rho * \operatorname{Exp}(1.239+1.980 * \operatorname{In}(\mathrm{DBH})+0.207 * \operatorname{In} \\
\left.(\mathrm{DBH})^{2}-0.0281 * \operatorname{In}(\mathrm{DBH})^{3}\right)(\mathrm{kg} / \text { tree })\end{array}$ & J. Chave et al. 2005 [22] \\
\hline
\end{tabular}

$\mathrm{AGB}=-238.341+353.062 \times \mathrm{SAVI}+19.491 \times \mathrm{RVI}\left(\mathrm{R}^{2}=0.813\right)$

\subsection{Biomass from SAR Data}

The application of Synthetic radar aperture data is a Promising Technique in Remote Sensing which uses high frequency wavelengths to estimate above ground biomass. Initially SAR data has to be process by both terrain 
Table 2. Field calculated biomass from allometric equations.

\begin{tabular}{|c|c|c|c|c|c|c|}
\hline S. No. & Plantation scientific name & No of trees & Mean DBH (cm) & Mean height (m) & Mean biomass (kg/tree) & Biomass (t/ha) \\
\hline 1 & Lemon Citrus & 24 & 10.466 & 2.445 & 22.512 & 6.003 \\
\hline 2 & Rose Apple Syzygiumjambos & 25 & 40 & 4.117 & 28.11 & 5.03 \\
\hline 3 & Mango Magnifera Indica & 24 & 99.401 & 6.191 & 112.327 & 29.954 \\
\hline 4 & Oil Palm Elaeis Guineensis & 20 & 231.6 & 8.537 & 605.843 & 134.631 \\
\hline 5 & Coconut Cocos Nucifera & 40 & 91.3 & 18.577 & 147.542 & 65.574 \\
\hline 6 & Coconut Cocos Nucifera & 36 & 91.44 & 9.744 & 79.534 & 31.813 \\
\hline 7 & $\begin{array}{c}\text { Banana, ca, Mango Musa } \\
\text { Magnifera Indi Acuminata } \\
\text { Mango }\end{array}$ & 63 & 51.44 & 4.657 & 112.048 & 78.433 \\
\hline 8 & $\begin{array}{l}\text { Mixed (Oil Elaeis Guineensis, } \\
\text { Palm, Mango Magnifera Indica, } \\
\text { Santol) Sandoricum Koetjape }\end{array}$ & 19 & 198.342 & 6.27 & 267.13 & 107.93 \\
\hline 9 & Oil Palm Elaeis Guineensis & 19 & 249.97 & 8.57 & 608.57 & 128.47 \\
\hline 10 & $\begin{array}{l}\text { Mixed Musa acuminate, (Lemon, } \\
\text { Sandoricum, Koetjap }\end{array}$ & 24 & 45.97 & 5.46 & 281.70 & 75.14 \\
\hline & Santol, Koetjape, Citrus Banana) & & & & & \\
\hline 11 & $\begin{array}{l}\text { Mixed Cocos Nucifera, (Mango, } \\
\text { Magnifera Indica Coconut) }\end{array}$ & 21 & 81.818 & 10.83 & 84.10 & 20.55 \\
\hline 12 & Oil Palm Elaeis Guineensis & 16 & 274.518 & 5.77 & 407.54 & 72.45 \\
\hline 13 & Oil Palm Elaeis Guineensis & 16 & 364.36 & 5.63 & 397.34 & 70.63 \\
\hline 14 & Oil Palm Elaeis Guineensis & 16 & 289 & 10.05 & 714.90 & 127.09 \\
\hline 15 & Oil Palm Elaeis Guineensis & 17 & 261.176 & 13.08 & 932.01 & 176.04 \\
\hline 16 & $\begin{array}{l}\text { Mixed Musa Acuminata, } \\
\text { (Banana, Cocos Nucifera } \\
\text { Coconut) }\end{array}$ & 65 & 47.99 & 4.81 & 104.50 & 75.47 \\
\hline 17 & Oil Palm Elaeis Guineensis & 25 & 255.6 & 11.105 & 790.21 & 219.50 \\
\hline 18 & Oil Palm Elaeis Guineensis & 25 & 211.4 & 3.32 & 231.49 & 64.30 \\
\hline 19 & Oil Palm Elaeis Guineensis & 16 & 245.75 & 8.16 & 579.35 & 102.99 \\
\hline 20 & Oil Palm Elaeis Guineensis & 17 & 282.78 & 7.29 & 516.74 & 97.60 \\
\hline
\end{tabular}

correction and radiometric calibration for calculating backscattering values. Radiometric calibration converts SAR data from DN (digital number) to backscattering coefficients $\left(\sigma^{\circ}\right)$ calculated in [dB] decibel values was mainly used for biomass model generation from SAR data. The SAR backscattering value calculated for both $\mathrm{HH}$ and $\mathrm{HV}$ polarization bands of ALOS-2 to generate new biomass model by comparing with biomass calculated from field data. To reduce noise reduction in SAR image mean adaptive filtering of kernel size $5 \times 5$ applied to increase the accuracy in biomass estimation. In order to compare the SAR backscattering values with field-calculated biomass the pixel size of ALOS-2 increased from $6.25 \mathrm{~m}$ to $30 \mathrm{~m}$ because sample plot size in study area is $30 \mathrm{~m}$. Linear regression analysis is utilized to find new biomass model from HH and HV backscattering coefficients of ALOS-2 SAR data which shows good relation with the field calculated biomass. HH backscattering coefficient was not considered in biomass model because it shows less relation $\left(R^{2}=0.405\right)$ with field calculated biomass compared to HV backscattering coefficients $\left(\mathrm{R}^{2}=0.775\right)$. Finally accurate biomass map is produced with HV backscattering as best fit model (Figure 5).

$$
\mathrm{AGB}=679.326+35.307 \times \sigma^{\circ}[\mathrm{dB}] \mathrm{HH}\left(\mathrm{R}^{2}=0.775\right)
$$




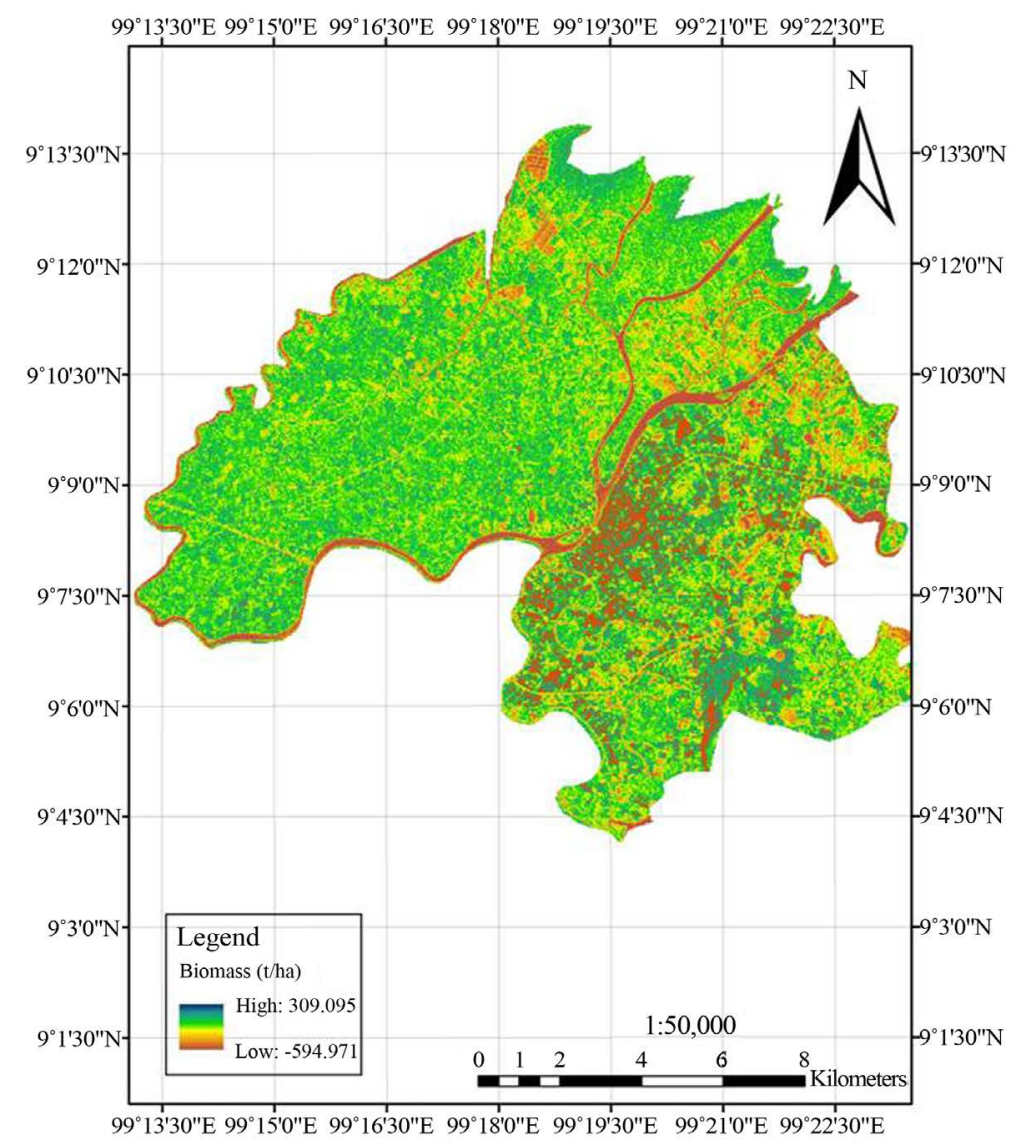

Figure 5. Biomass map from SAR (ALOS-2) data.

\subsection{Biomass from Combined Optical and SAR Data}

Combination of both optical and SAR remote sensing data leads to new techniques in biomass estimation. Both optical (LANDSAT 8) and SAR (ALOS-2) remote sensing data applied to develop new biomass model by finding relation with field-calculated biomass. Multi linear regression is used to develop high accuracy biomass model $\left(\mathrm{R}^{2}=0.87\right)$ by comparing both spectral indices (SAVI, RVI) of LANDSAT 8 and HV backscattering values of ALOS-2 with field calculated biomass. Accurate biomass equation is produced with SAVI, RVI and HV SAR backscattering as best fit model $\left(\mathrm{R}^{2}=0.87\right)$ applied to total study area (Figure 6).

$$
\mathrm{AGB}=101.819+17.866 \times \sigma^{\circ}[\mathrm{dB}] \mathrm{HV}+442.344 \times \mathrm{SAVI}+9.113 \times \mathrm{RVI}\left(\mathrm{R}^{2}=0.870\right)
$$

\section{Results}

Accuracy assessment for all biomass models has to be checked with total 20 field sample plots. Linear regression analysis is applied for accuracy validation of each biomass map by checking the biomass value of 20 field sample plots with the biomass value obtained from satellite imagery. From the results it shows that biomass map generated from spectral indices of Optical sensor data shows good accuracy $\left(\mathrm{R}^{2}=0.788\right)$ with RMSE of 26.054 $(\mathrm{t} / \mathrm{ha})$. SAR backscattering biomass map accuracy was not higher $\left(\mathrm{R}^{2}=0.74\right)$ than spectral biomass map. Combination of both optical (spectral indices) and SAR (HV backscattering) increases biomass accuracy to $\left(\mathrm{R}^{2}=\right.$ 0.859) with RMSE of 21.20 (t/ha) compared to biomass models of optical and SAR data (Table 3).

\section{Conclusion}

In this study the application of remote sensing in biomass assessment is introduced. Both optical (LANDSAT-8) 
BIOMASS MAP FROM COMBINED OPTICAL AND SAR DATA

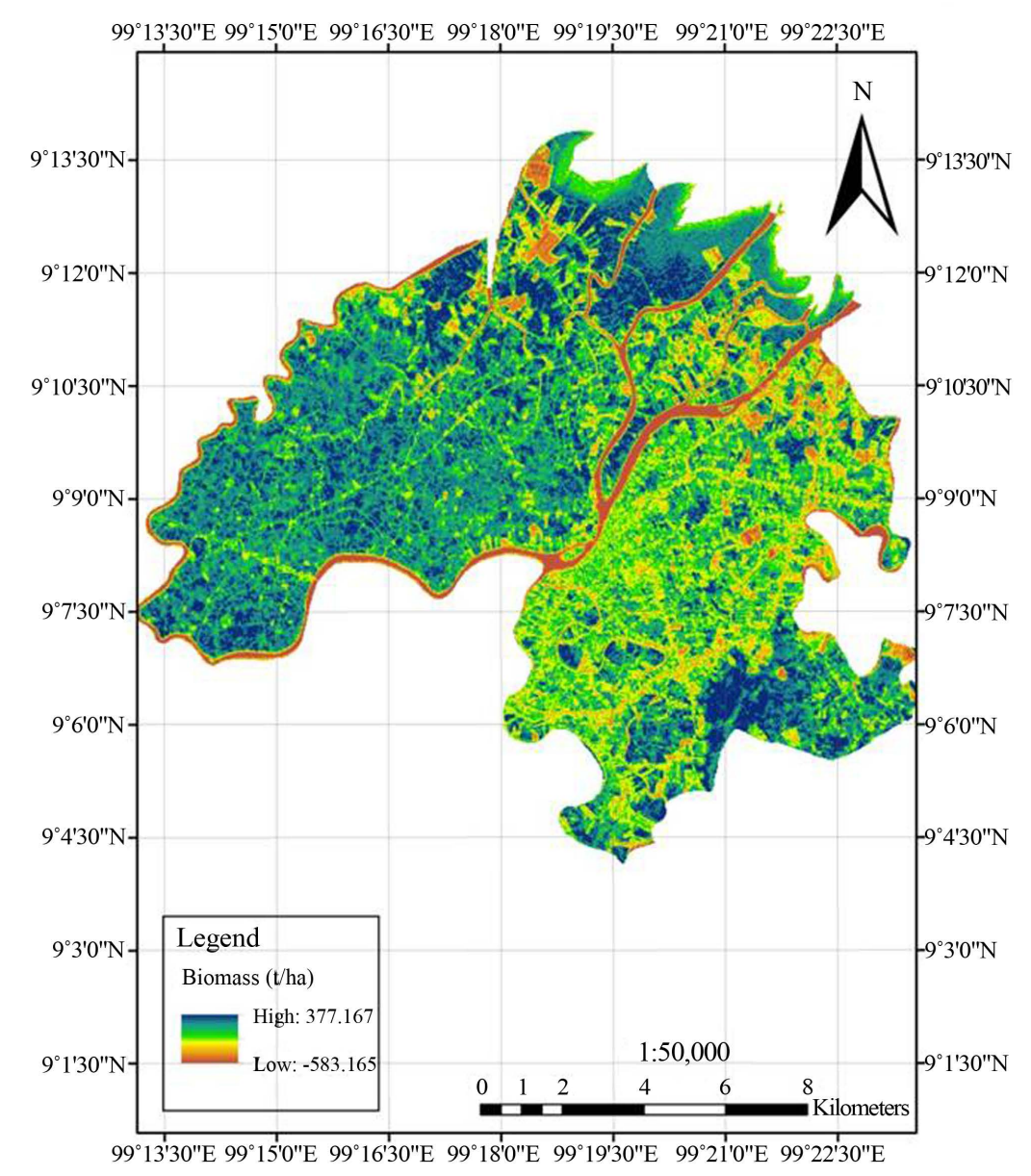

Figure 6. Biomass map from combined SAR and optical data.

Table 3. Accuracy results of biomass models.

\begin{tabular}{cccc}
\hline S.NO & Data & $\mathrm{R}^{2}$ & RMSE \\
\hline 1 & Optical (LANDASAT-8) & 0.788 & 26.054 (t/ha) \\
2 & SAR (ALOS-2) & 0.742 & 28.736 (t/ha) \\
3 & Combined (Optical \& SAR) & 0.859 & 21.207 (t/ha) \\
\hline
\end{tabular}

and synthetic aperture radar (ALOS-2) remote sensing data are used for above ground biomass (AGB) assessment. The overall accuracy of classified map from optical data (LANDSAT-8) indicates that different land features on map show an accuracy of $91.13 \%$ with the original land features on the ground. Biomass map developed from spectral indices of both SAVI and RVI shows good accuracy $\left(\mathrm{R}^{2}=0.81\right)$ compared to SAVI and EVI $\left(\mathrm{R}^{2}=\right.$ $0.75)$ spectral indices. Only HV backscattering $\left(\mathrm{R}^{2}=0.77\right)$ of ALOS-2 shows good relation with the field biomass compared to HH backscattering $\left(\mathrm{R}^{2}=0.4\right)$. Application of combined optical and SAR data provides high accurate biomass map $\left(\mathrm{R}^{2}=0.859\right)$ which leads to implementation of different techniques in biomass research.

\section{Acknowledgements}

The authors would like to thank Japan Aerospace Agency (JAXA) for supplying ALOS-2 images with in project time. The authors would like to thank Office of Agriculture Research and Development at Surat Thani for supporting field data collection. 


\section{References}

[1] Carreiras, J.M.B., Vasconcelos, M.J. and Lucas, R.M. (2012) Understanding the Relationship between Aboveground Biomass and ALOS PALSAR Data in the Forests of Guinea-Bissau (West Africa). Remote Sensing of Environment, 121, 426-442. http://dx.doi.org/10.1016/j.rse.2012.02.012

[2] Rosenqvist, Å., Milne, A., Lucas, R., Imhoff, M. and Dobs, C. (2003) A Review of Remote Sensing Technology in Support of Kyoto Protocol. Environmental Science \& Policy, 6, 441-455. http://dx.doi.org/10.1016/S1462-9011(03)00070-4

[3] Ji, L., Wylie, B.K., Nossov, D.R., Peterson, B., Waldrop, M.P., McFarland, J.W., Rover, J. and Hollingsworth, T.N. (2012) Estimating Aboveground Biomass in Interior Alaska with Landsat Data and Field Measurements. International Journal of Applied Earth Observation and Geoinformation, 18, 451-461. http://dx.doi.org/10.1016/j.jag.2012.03.019

[4] Wang, X.Q., Pangb, Y., Zhang, Z.J. and Yuan, Y. (2014) Forest Aboveground Biomass Estimation Using SPOT-5 Spectral Indices and Textural Derivatives. IEEE Transactions on Geoscience and Remote Sensing, 2830-2832.

[5] Yin, G.D., Zhang, Y., Sun, Y., Wang, T., Zeng, Z.Z. and Piao, S.L. (2015) MODIS Based Estimation of Forest Aboveground Biomass in China. Remote Sensing, 7, 5534-5564.

[6] Thenkabail, P.S., Stucky, N., Griscom, B.W., Ashton, M.S., Diels, J., Van der Meer, B. and Enclona, E. (2004) Biomass Estimations and Carbon Stock Calculations in the Oil Palm Plantations of African Derived Savannas Using IKONOS Data. International Journal of Remote Sensing, 25, 1-27. http://dx.doi.org/10.1080/01431160412331291279

[7] Eckert, S. (2012) Improved Forest Biomass and Carbon Estimations Using Texture Measures from WorldView-2 Satellite Data. Remote Sensing, 4, 810-829. http://dx.doi.org/10.3390/rs4040810

[8] Baghdadi, N., le Maire, G., Bailly, J.-S., Osé, K., Nouvellon, Y., Zribi, M., Lemos, C. and Hakamada, R. (2014) Evaluation of ALOS PALSAR-L Band for the Estimation of Eucalyptus Plantation Aboveground Biomass in Brazil. IEEE Transactions on Geoscience and Remote Sensing, 721-724.

[9] Zhang, Y. and Jing, Z.-X. (2001) Estimating Paddy Rice Biomass Using Radarasat-2 Data Based on Artificial Neutral Network. International Conference on Remote Sensing, Environment and Transportation Engineering (RSETE 2013), 423-426.

[10] Pierce, L., Liang, P., Dobson, M.C., Kellndorfer, J., Barros, O., dos Santos, J.R. and Soares, J.V. (2003) Regrowth Biomass Estimation in Amazon Using JERS-1/RADARSAT SAR Composites. IEEE Transactions on Geoscience and Remote Sensing, 3, 2075-2077. http://dx.doi.org/10.1109/igarss.2003.1294297

[11] Englhart, S., Keuck, V. and Siegert, F. (2011) Aboveground Biomass Retrieval in Tropical Forests. The Potential of Combined X- and L-Band SAR Data Use. Remote Sensing of Environment, 115, 1260-1271. http://dx.doi.org/10.1016/j.rse.2011.01.008

[12] Kumar, S., Pandey, U., Kushwaha, S.P.S., Chatterjee, R.S. and Bijiker, W. (2012) Tropical Forest from Envisat ASAR Using Modeling Approach. Journal of Applied Remote Sensing, 6.

[13] Cartus, O., Santoro, M. and Kellndorfer, J. (2012) Mapping Forest Aboveground Biomass in the Northeastern United States with ALOS PALSAR Dual-Polarization L-Band. Remote Sensing of Environment, 124, 466-478. http://dx.doi.org/10.1016/j.rse.2012.05.029

[14] Ranson, K.J. and Sun, G.Q. (1994) Mapping Biomass of Northern Forest Using Multifrequency SAR Data. IEEE Transcationson Geoscience and Remote Sensing, 32, 388-396. http://dx.doi.org/10.1109/36.295053

[15] Hamdan, O., Aziz, H.K. and Rahman, A. (2011) Remotely Sensed L Band SAR Data for Tropical Forest Biomass Estimation. Journal of Tropical Forest Science, 23, 318-324.

[16] Tanase, M.A., Panciera, R., Lowell, K., Tian, S., Hacker, J.M. and Walker, J.P. (2014) Airborne Multi-Temporal LBand Polarimetric SAR Data for Biomass Estimation in Semi-Arid Forests. Remote Sensing of Environment, 145, 93104. http://dx.doi.org/10.1016/j.rse.2014.01.024

[17] Goh, J.Y., Miettinen, J., Chia, A.S., Chew, P.T. and Liew, S.C. (2013) Biomass Estimation in Humid Tropical Using Combination of Both ALOS PALSAR and SPOT 5 Satellite Image. Asian Journal of Geoinformatics, 13, 1-10.

[18] Asari, N., Suratman, M.N., Jaafar, J. and Khalid, M.M. (2013) Estimation of above Ground Biomass for Oil Plantations Using Algometric Equations. 4th International Conference on Biology, Environment and Chemistry, 58, 110-114.

[19] Hairiah, K., Dewi, S., Agus, F., Velarde, S., Ekadinata, A., Rahayu, S. and van Noordwijk, M. (2010) Measuring Carbon Stocks across Land Use Systems: A Manual. World Agroforestry Centre (ICRAF), SEA Regional Office, Bogor, $154 \mathrm{p}$.

[20] Chavan, B. and Rasal, G. (2012) Total Sequestered Carbon Stock of Mangifera indica. Journal of Environment and Earth Science, 2, 37-49.

[21] Bwalya, J.M. (2012) Estimation of Net Carbon Sequestration Potential of Citrus under Different Management Systems 
Using the Life Cycle Approach.

[22] Chave, J., Andalo, C., Brown, S., Cairns, M.A., Chambers, J.Q., Eamus, D., Folster, H., Fromard, F., Higuchi, N., Kira, T., Lescure, J.P., Nelson, B.W., Ogawa, H., Puig, H., Riera, B. and Yamakura, T. (2005) Tree Allometry and Improved Estimation of Carbon Stocks and Balance in Tropical Forests. Oecologia, 145, 87-99.

http://dx.doi.org/10.1007/s00442-005-0100-x

\section{Submit or recommend next manuscript to SCIRP and we will provide best service for you:}

Accepting pre-submission inquiries through Email, Facebook, LinkedIn, Twitter, etc.

A wide selection of journals (inclusive of 9 subjects, more than 200 journals)

Providing 24-hour high-quality service

User-friendly online submission system

Fair and swift peer-review system

Efficient typesetting and proofreading procedure

Display of the result of downloads and visits, as well as the number of cited articles

Maximum dissemination of your research work

Submit your manuscript at: http://papersubmission.scirp.org/ 